\section{UK plans for coping with plutonium waste fail to impress}

[LONDON] More than 100 members of Britain's Parliament last week signed a motion criticizing the government for failing to develop a policy for managing plutonium removed from dismantled nuclear weapons. The MPs also opposed the decision to convert part of the plutonium stockpile into mixed oxide fuel (MOX) for nuclear power reactors.

The MPs want to halt plans to build a $\mathfrak{E 5 0 0}$-million (US\$800-million) MOX recycling plant until a review of policy has been completed. Their public statement coincides with the publication of the report of a twoyear study, coordinated by the Citizens' Nuclear Information Center in Tokyo and the World Information Service on Energy in Paris, which concludes that recycling MOX could lead to plutonium proliferation.

MOX is made by mixing oxides of uranium with small quantities (5-10 per cent) of oxides from weapons-grade plutonium. Some countries, including Britain, France, Germany and Japan, are considering the manufacture of MOX as a way of reducing plutonium stockpiles. They also believe it to be a useful alternative to fossil fuels.

The authors of the international MOX assessment study argue that such a strategy could be counterproductive. They contend that it will keep plutonium in circulation for longer than necessary, increasing the risk of its misuse by terrorists. They also point out that the quantity of plutonium in the MOX mixture is too small to make a dent in the stockpiles. France has over 40 tonnes of plutonium stockpiled, and Britain over 50 tonnes.

The study also raises questions about security at plutonium stores, claiming that site operators, particularly in Britain, lack the capability to trace material that is stolen or illegally diverted to weapons making.

Site operators aim to keep 'unaccountedfor material' to below $8 \mathrm{~kg}$, the minimum quantity estimated by the International Atomic Energy Agency to be needed to make a nuclear device. But the MOX study claims that the Thermal Oxide Reprocessing Plant operated by British Nuclear Fuels at Sellafield in northwest England cannot detect missing plutonium unless the material weighs more than $220 \mathrm{~kg}$.

The study claims that a minimum weekly inventory of plutonium stocks is needed to detect stolen or diverted material quickly "instead of every year as practised today".

But such claims are rejected by Peter Metcalfe of British Nuclear Fuels. "The plutonium is subject to very strict checks and safeguards by multinational teams of inspectors to ensure that it is safely handled and accounted for," he says.

Ehsan Masood

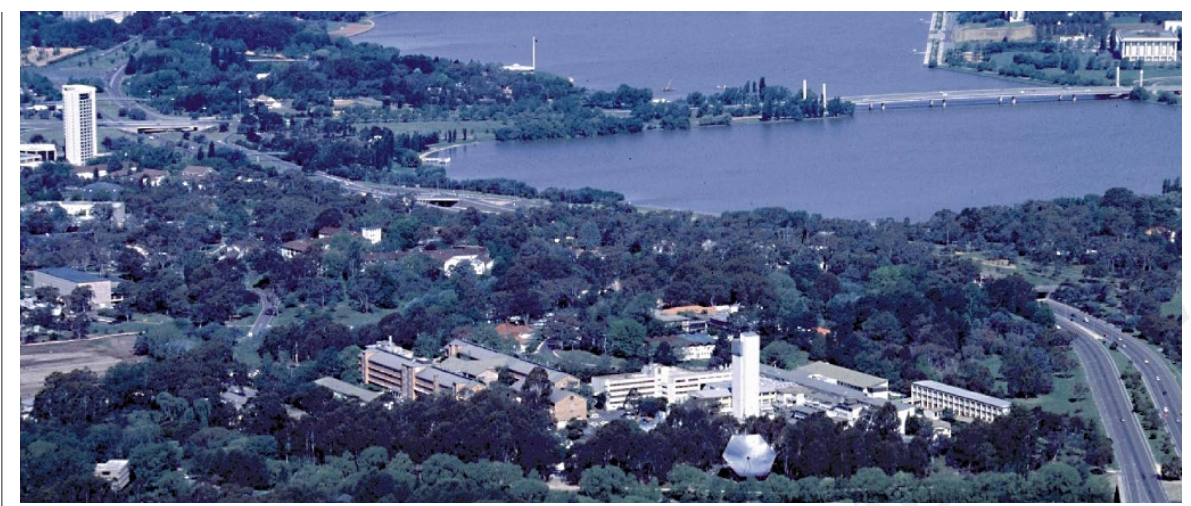

Troubled waters: the ANU campus, with the Institute of Advanced Studies in the centre foreground.

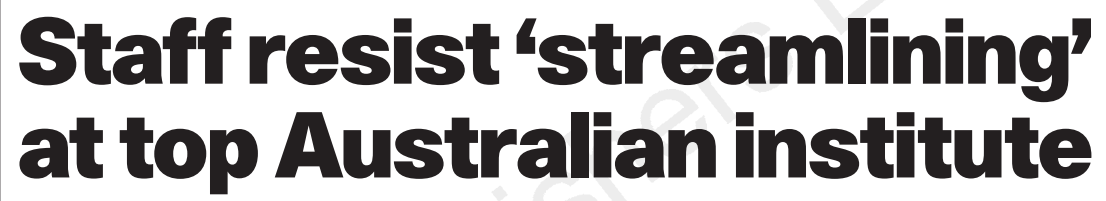

[CANBERRA] Tension is running high at the Australian National University (ANU) in Canberra, where efforts to absorb a 14 per cent cut in government funding over four years have included a move to change the management of its renowned Institute of Advanced Studies (IAS).

The past two months have seen both the closure of the university's Division of Archaeology and Natural History and the resignation of Sue Serjeantson, one of its two deputy vice-chancellors, who had also been director of the IAS since 1993.

The archaeology group had built an international reputation for its work on the prehistory of Australia's indigenous people (see for example, Roberts et al., Nature 387, 696-699; 1997). The group's fate is seen as an example of the damage that can be done when the government cuts university funding without a clear policy.

Founded as a research-based university 51 years ago, ANU recently emerged from two major external reviews of the IAS with an acknowledgement of the quality of research in its seven schools, and with little change to its unusual funding arrangements or the federated structure of its teaching and research departments (known as 'The Faculties').

A unique feature of the IAS, which has enabled it to attract researchers of international standing, has been the arrangement under which it receives an annual block grant of \$A150 million (\$US105 million) from the government, two-thirds of the total grant to the ANU.

The resulting autonomy has allowed the IAS (1,590 staff out of 3,570 for the whole of ANU) to set its own priorities and carry out long-term studies unaffected by the shortterm perspective forced upon researchers in other universities.

Although Serjeantson has not revealed the reasons for her resignation, which followed a review of ANU's senior management structure by Peter Karmel, a former ANU vice-chancellor, it is widely believed to have been triggered by a perceived threat to the special characteristics of the institute. Karmel's panel proposed abolishing her post on the grounds that the university's administration should be more streamlined at a time of "uncertainty, competition, change and constrained funding".

Karmel's recommendation of a merger between the managements of the IAS and The Faculties sparked vehement protests by staff concerned at a lack of consultation. They also claimed that the university's reputation would suffer if the traditional 'collegiality' of decision-making was replaced by 'managerialism' and the privatization of some of its activities in the search for nongovernment funding.

These claims have been rejected by the the management plan as "an effective way of integrating collegial academic responses to issues" which will "protect and enhance Australia's pre-eminent research groups in the IAS".

Under a structure revised following objections, the institute will continue to have a director. But although the post will be at the same salary as a (sole) deputy vice-chancelresources and responsibility for research in both the IAS and The Faculties.

A vote last month at a meeting of the university's governing council was tied between academics seeking to defer the plan and administrators in favour of immediate implementation. The casting vote of the university's chancellor, Peter Baume, allowed Terrell to win the restructuring, but he gave the two academic boards a month's grace to comment on details.

Both boards describe the plan as "confusing" and want the council to restore responsibilities to the director of the IAS and the parallel post of chair of The Faculties board.

PeterPockley vice-chancellor, Deane Terrell, who describes lor, the latter will have direct control over 